ISSN 1678-3921

Journal homepage: www.embrapa.br/pab

For manuscript submission and journal contents, access: www.scielo.br/pab

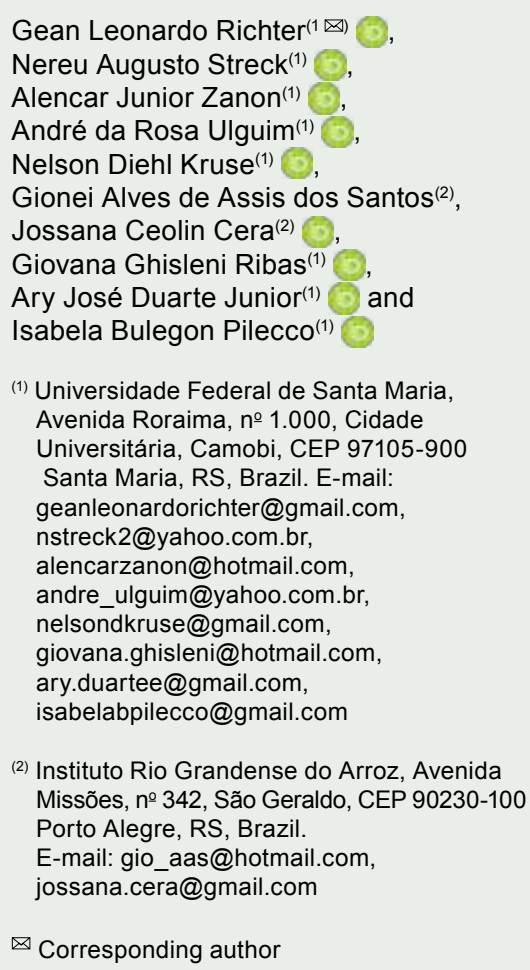

\section{Introducing rice yield loss caused by weed competition into the SimulArroz model}

\begin{abstract}
The objective of this work was to model weedy rice (Oryza sativa) and barnyard grass (Echinochloa spp.) competition with flood-irrigated rice, introducing it as a submodule into the SimulArroz model. The competition of both weeds with irrigated rice was modeled using the rectangular hyperbola equation. The " $\mathrm{i}$ " and "a" coefficients of the rectangular hyperbola for each of these weeds were obtained from the literature and from field experiments carried out in the state of Rio Grande do Sul, Brazil. In SimulArroz, yield loss was applied to penalize yield in all three technological levels (high, medium, and low) of physiological maturity. For weedy rice, the coefficient values of $\mathrm{i}_{\text {mean }}$ for the high, medium, and low technological levels were 1.04, 1.50, and 3.57 respectively, and, for barnyard grass, 4.70, 10.49, and 15.51 respectively. Coefficient "a" was 100 for weedy rice, and a $a_{\text {mean }}$ values for barnyard grass were 101.63, 104.92, and 96.88 for the high, medium, and low levels, respectively. The yield loss approach was suitable to model the competition of weedy rice and barnyard grass with irrigated rice. The submodule yield loss caused by the competition of weedy rice and barnyard grass with irrigated rice improves the predictive capacity of the SimulArroz model.
\end{abstract}

Index terms: Oryza sativa, barnyard grass, modeling, weedy rice, yield loss.

\section{Introdução da perda de produtividade de arroz pela competição com plantas daninhas no modelo SimulArroz}

Resumo - O objetivo deste trabalho foi modelar a competição de arrozdaninho (Oryza sativa) e capim-arroz (Echinochloa spp.) com o arroz irrigado por inundação e introduzi-la como um submodelo no modelo SimulArroz. A competição das duas ervas daninhas com o arroz irrigado foi modelada com o uso da equação da hipérbole retangular. Os coeficientes "i" e "a" da hipérbole retangular referentes a cada erva foram obtidos na literatura e em experimentos de campo conduzidos no Rio Grande do Sul. No SimulArroz, a perda de produtividade foi aplicada para penalizar a produtividade nos três níveis tecnológicos (alto, médio e baixo) para maturidade fisiológica. Para o arroz-daninho, os valores do coeficiente $i_{\text {médio }}$, para os níveis tecnológicos alto, médio e baixo, foram $1,04,1,50$ e 3,57, respectivamente, e, para o capimarroz, foram 4,70, 10,49 e 15,51, respectivamente. O coeficiente "a" foi 100 para o arroz-daninho, e o $a_{\text {médio, }}$ para o capim-arroz, foi 101,63, 104,92, 96,88 para os níveis tecnológicos alto, médio e baixo, respectivamente. A abordagem de perda de produtividade foi adequada para modelar a competição de arrozdaninho e capim-arroz com o arroz irrigado. O submodelo de perda de produtividade pela competição de arroz-daninho e capim-arroz com o arroz irrigado melhora a capacidade preditiva do modelo SimulArroz.

Termos para indexação: Oryza sativa, capim-arroz, modelagem, arrozdaninho, perda de produtividade. 


\section{Introduction}

Brazil is the first largest rice (Oryza sativa L.) producer in the world outside Asia (FAO, 2019), and has an annual production of around 11 tons. The state of Rio Grande do Sul is the largest rice producer in Brazil, and accounts for $70 \%$ of the national production (Conab, 2019) on 1.1 million hectare of flood-irrigated system (Conab, 2019). An analysis of the rice time series from 2012 to 2018 in Rio Grande do Sul shows a steady increase in yield of up to $8.0 \mathrm{Mg} \mathrm{ha}^{-1}$, but this value is below the best yields obtained by farmers in the state, which is of $12 \mathrm{Mg} \mathrm{ha}^{-1}$ (Ribas et al., 2016). One of the major factors causing the gap between average state yield and best yield is the unsatisfactory weed control (Rubin et al., 2014).

Weeds are the main causes of biotic stress in agricultural crops, because they compete for resources (solar radiation, water and nutrients) with the crop of economic interest (Agostinetto et al., 2007; Olajumoke et al., 2016). The most important rice weeds are those which belong to the same family (Poaceae), mainly weedy rice (Oryza sativa) and barnyard grass (Echinochloa spp.). Weedy rice belongs to the same species as cultivated rice, is characterized as its main weed (Olajumoke et al., 2016), and limits the increase in rice yield in Rio Grande do Sul (Rubin et al., 2014). Barnyard grass is also reportedly one of the most important weeds worldwide (Aminpanah et al., 2012). Well adapted to survive in flooded environments, it shows high infestation levels in paddy rice fields in Rio Grande do Sul. Yield losses in rice due to weedy rice and barnyard grass have been reported to vary from less than 1 to up to $30 \%$ of losses (Agostinetto et al., 2004; Galon et al., 2007).

The weed competition model that best biologically explains crop yield losses due to weed competition is the rectangular hyperbola (Cousens, 1985; Moon et al., 2011; Mamun, 2014). According to this approach, crop yield losses at low weed densities (when interspecific crop-weed competition predominates) show linear responses (Adati et al., 2006). As weed density increases, intraspecific competition increases, leading to a nonlinear response with a decreasing yield-loss rate, so that in crops showing very high weed density, yield loss approaches its maximum when competition among weed individuals begins (Adati et al., 2006). The rectangular hyperbola has two empirical coefficients, "i" and "a", which must be estimated from observation data collected in field experiments (Adati et al., 2006).

The use of submodels, such as weed competition submodels, into crop-based models, such as Oryza2000 (Li et al., 2017), InfoCrop (Aggarwal et al., 2006), RiceGrow (Tang et al., 2009) and SimulArroz (Ribas et al., 2017), increases the applicability of the models to yield simulations. SimulArroz is a process-based model that simulates growth, development, and yield of irrigated rice on a daily time step. This model differs from the others for having been adapted for cultivars grown under flood irrigation system in the state of Rio Grande do Sul (Walter et al., 2012; Ribas et al., 2017). Grain yield and yield components are calculated by equations described in the InfoCrop (Aggarwal et al., 2006) and Oryza2000 (Li et al., 2017) models, specifically calibrated for the most used cultivars in flooded rice systems in Southern Brazil.

Phenology is calculated in SimulArroz by the thermal time approach $\left({ }^{\circ} \mathrm{C}\right.$ day), using the lower and upper basal (temperatures below and above which plant development is negligible, respectively) and optimum temperatures (at which the development rate is maximum) (Streck et al., 2011). The dry matter production is calculated through the radiation use efficiency (RUE) and the leaf area index (LAI), in which RUE is described as a function based on cardinal temperatures. The daily dry matter production is partitioned among roots, leaves, stems and panicles, according to developmental stage and cultivar. The LAI is calculated using the dry matter sent to the leaves $\left(\mathrm{g} \mathrm{m}^{-2}\right.$ per day) and the specific leaf area $\left(\mathrm{m}^{2} \mathrm{~g}^{-1}\right)$ varies according to cultivar and developmental stage.

The current version of the SimulArroz model is not equipped with a module that simulates weed-crop competition and its effect on rice yield. Instead, biotic factors that affect rice yield are assembled empirically in SimulArroz into three "technological levels" (high, medium, and low) of farms. In a farm with high technological level, weed control is assumed to be well done and thus to cause negligible effect on rice yield; in a farm with low technological level, weed control is unsatisfactory and there is high loss in rice yield, due to weed competition, and farming is not economically viable. The medium technological level is intermediate between the two levels above (Walter et al., 2012). This empirical approach has enabled to reproduce the technological level of famers at a county and state 
level, so that the SimulArroz model was used for redefining the Agroclimatic Zoning of rice in the state for the first time in history (Brasil, 2018). However, on a farm level, there is clearly a need to introduce a more process-based approach that can depict on-farm variability in weed control.

The objective of this work was to model weedy rice and barnyard grass competition with irrigated rice, introducing it as a submodule into the SimulArroz model.

\section{Materials and Methods}

The weed competition effect on irrigated rice yield was modeled using the yield loss approach (Adati et al., 2006) and the rectangular hyperbola (Cousens, 1985) with equations:

$$
\begin{gathered}
Y_{L}=(i D)(1+\beta D)^{-1} \\
\beta=\mathrm{ia}^{-1}
\end{gathered}
$$

Weed density was used as predictive variable. Weedy rice and barnyard grass were used in this study, as they are the most important weeds in irrigated rice crops. $\mathrm{Y}_{\mathrm{L}}$ is the yield loss, in percentage, related to the control treatment (without weed competition); $\mathrm{D}$ is the weed density in plants per square meter; $i$ is the yield loss, in percentage, of rice grains per unit of weed when weed density approaches zero; a is the yield loss, in percentage, of rice grains when weed density approaches infinity; and $\beta$ is the weed's competitiveness (Cousens, 1985; Mamun, 2014).

The $i$ and a coefficients of the rectangular hyperbola model for each of the weed species were obtained from studies carried out in the state of Rio Grande do Sul and published in the literature (Tables 1 and 2). In addition, the inverse of the competitiveness of each weed was calculated, which represents the density of weeds that reduces yield by $50 \%$. This parameter facilitates the understanding of the competition for

Table 1. Coefficient i (for yield loss, in percentage, of rice (Oryza sativa) grains per unit of weed when weed density approaches zero) and coefficient a (for yield loss, in percentage, of rice grains when weed density approaches infinity) of the

\begin{tabular}{|c|c|c|c|c|}
\hline Coefficient i & Coefficient a & Cultivar & Level & Reference \\
\hline 0.25 & 100 & IRGA 417 & High & Agostinetto et al. (2005a) \\
\hline 0.49 & 100 & IRGA 417 & High & Fleck et al. (2004) \\
\hline 0.50 & 100 & BR-IRGA 409 & High & Fleck et al. (2004) \\
\hline 0.51 & 100 & BR-IRGA 409 & Low & Agostinetto et al. (2005b) \\
\hline 0.63 & 100 & BRS-38 Ligeirinho & High & Fleck et al. (2004) \\
\hline 0.70 & 100 & BRS-38 Ligeirinho & Medium & Fleck et al. (2004) \\
\hline 0.72 & 100 & BRS-38 Ligeirinho & Medium & Fleck et al. (2004) \\
\hline 0.75 & 100 & BRS-38 Ligeirinho & High & Fleck et al. (2004) \\
\hline 0.77 & 100 & BR-IRGA 409 & Medium & Agostinetto et al. (2005a) \\
\hline 0.77 & 100 & BR-IRGA 409 & Medium & Fleck et al. (2004) \\
\hline 0.94 & 100 & BR-IRGA 409 & Low & Agostinetto et al. (2005b) \\
\hline 0.97 & 100 & IRGA 417 & Low & Agostinetto et al. (2005b) \\
\hline 1.23 & 100 & BRS-38 Ligeirinho & High & Agostinetto et al. (2005b) \\
\hline 1.25 & 100 & IRGA 417 & High & Agostinetto et al. (2005b) \\
\hline 1.25 & 100 & IRGA 417 & High & Agostinetto et al. (2005b) \\
\hline 1.25 & 100 & BR-IRGA 409 & High & Agostinetto et al. (2005b) \\
\hline 1.25 & 100 & IRGA 417 & Medium & Agostinetto et al. (2005a) \\
\hline 1.30 & 100 & BR-IRGA 409 & High & Agostinetto et al. (2005b) \\
\hline 1.37 & 100 & IRGA 417 & High & Agostinetto et al. (2005b) \\
\hline 1.50 & 100 & BRS-38 Ligeirinho & Medium & Agostinetto et al. (2005b) \\
\hline 1.51 & 100 & IRGA 417 & Low & Agostinetto et al. (2005b) \\
\hline 1.54 & 100 & BRS-38 Ligeirinho & High & Agostinetto et al. (2005b) \\
\hline 1.67 & 100 & IRGA 417 & High & Agostinetto et al. (2005a) \\
\hline 1.74 & 100 & BR-IRGA 409 & Medium & Agostinetto et al. (2005b) \\
\hline 1.95 & 100 & IRGA 417 & Medium & Agostinetto et al. (2005b) \\
\hline 4.07 & 100 & IRGA 417 & Medium & Agostinetto et al. (2005a) \\
\hline 4.81 & 100 & IRGA 417 & Low & Agostinetto et al. (2005a) \\
\hline 12.65 & 100 & IRGA 417 & Low & Agostinetto et al. (2005a) \\
\hline
\end{tabular}
rectangular hyperbola equation $\left(\mathrm{Y}_{\mathrm{L}}=(\mathrm{iD})(1+\beta \mathrm{D})^{-1}\right)$ for weedy rice (Oryza sativa) in the rice crop. 
different rectangular hyperbolas (Cousens, 1985; Mamun, 2014):

$$
\mathrm{S}=1 \beta^{-1}
$$

The module of yield loss due to weeds was introduced into the SimulArroz model to penalize yield at each of the three technological levels on the day of physiological maturity. The assumption was that competition occurs from the period prior to interference (PPI) up until physiological maturity, regardless of the technological level chosen. The source code for SimulArroz is available in Fortran, and the necessary measures for coupling equation 1 into the model were made. For this reason, the rectangular hyperbolas in Tables 1 and 2 were classified according to technological level (high, medium, and low). Crops with high technological level follow the principles of Project 10+ (Menezes et al., 2012), such as high fertilization, onset of flooded irrigation at V3 and a plant density of 200 plants per square meter. As low technological level were considered the experimental treatments with reduced use and incorrect application of fertilization, greater plant line spacing, delay in the onset of flooded irrigation and lack of application of pesticides at the right time. The medium level is intermediate between the high and low levels. After classification, the average values of $i_{\text {mean }}$ and $a_{\text {mean }}$ were calculated for each weed species and technological level.

As independent data to test the model, four experiments were conducted in a completely randomized design for evaluating weed density and rice yield for both weeds; with one unit by combination of factors, the different densities functioned as repetitions and provided variance for the statistical analyses performed using the nonlinear model proposed by Cousens (1985).

For the weedy rice, two experiments were conducted in commercial farm fields during the 2016/2017 growing season in São João do Polêsine and Santa Maria, in Rio Grande do Sul, and were subjected to the farmer's management practices. Those two areas were chosen due to their historical weedy rice infestation.

To test the effect of barnyard grass on irrigated rice yield, two field experiments were carried out at Estação Experimental do Arroz in Instituto Rio Grandense de Arroz (IRGA), located in the municipality of Cachoeirinha, also in the state of Rio Grande do Sul, during the 2016/2017 growing season. Plant density of the weeds was defined when the rice plants were at the V3-V4 stage; using plastic cups or pieces of paper, barnyard plants were protected against the cyhalofop-

Table 2. Coefficient i (for yield loss, in percentage, of rice (Oryza sativa) grains per unit of weed when weed density approaches zero) and coefficient a (for yield loss, in percentage, of rice grains when weed density approaches infinity) of the rectangular hyperbola equation $\left(\mathrm{Y}_{\mathrm{L}}=(\mathrm{iD})(1+\beta \mathrm{D})^{-1}\right)$ for barnyard grass $($ Echinochloa $\mathrm{spp}$.) in the rice crop.

\begin{tabular}{|c|c|c|c|c|}
\hline Coefficient i & Coefficient a & Cultivar & Level & Reference \\
\hline 1,134 & 100.00 & IRGA 424 RI & High & Beck et al. (2017) \\
\hline 1,1715 & 100.00 & Guri INTA CL & High & Beck et al. (2017) \\
\hline 4.62 & 107.30 & BRS Pelotas & High & Agostinetto et al. (2010) \\
\hline 4.71 & 107.10 & IRGA 417 & High & Galon et al. (2007) \\
\hline 6.01 & 98.97 & BRS Pelotas & Low & Agostinetto et al. (2010) \\
\hline 7.22 & 112.50 & IRGA 416 & Medium & Galon et al. (2007) \\
\hline 8.14 & 96.30 & BRS Pelotas & High & Agostinetto et al. (2010) \\
\hline 8.40 & 99.09 & BRS Pelotas & High & Agostinetto et al. (2007) \\
\hline 9.79 & 108.30 & IRGA 421 & Medium & Galon et al. (2007) \\
\hline 10.40 & 104.30 & BRS Pelotas & Medium & Agostinetto et al. (2007) \\
\hline 11.25 & 97.41 & BRS Pelotas & Low & Agostinetto et al. (2007) \\
\hline 11.38 & 96.19 & BRS Atlanta & Medium & Galon et al. (2007) \\
\hline 13.67 & 101.10 & BRS Fronteira & Medium & Galon et al. (2007) \\
\hline 29.27 & 94.27 & AVAXI & Low & Galon et al. (2007) \\
\hline
\end{tabular}


butyl herbicide commercial product applied at a dose of $1.5 \mathrm{~L} \mathrm{ha}^{-1}$.

Sites, weed, sowing date, cultivar, fertilizer, and technological levels used in each experiment for weedy rice and barnyard grass are listed in Table 3. Weed density evaluations for all experiments were carried out in nine-row plots with $0.17-\mathrm{m}$ and $6.0-\mathrm{m}$-long spacing, by counting the individuals in a $0.5-\mathrm{m}^{2}$ area subdivided into two sites for each plot, and randomly selected. The yield was quantified using the harvested plots, and the grains obtained were corrected to a $13 \%$ moisture rate. The yield loss of the weed plots was calculated in relation to the plots maintained without infestation.

The observed data were compared with the values estimated by the SimulArroz model using the competition module for both weeds, with $i_{\text {mean }}$ and $a_{\text {mean }}$ for the weed and the technological level for all four conducted experiments. The performance was evaluated using statistics: root mean square error (RMSE), normalized root mean square error (RMSEn), BIAS index (Samboranha et al., 2013), modified index of agreement (dw) (Willmott et al., 1985), and Nash-Sutcliffe efficiency coefficient (COE) (Nash \& Sutcliffe, 1970).

\section{Results and Discussion}

The $\mathrm{i}_{\text {mean }}$ values for high, medium and low technological levels were 1.04, 1.50, and 3.57, respectively (Table 4). Lower values of imean for the high technological level mean that the unit loss (yield loss of one weedy rice per square meter) is lower when managementis bettercarriedoutby farmers(Agostinetto et al., 2004, 2007). Differently, in the experiments or treatments classified as low technological level, the $\mathrm{i}_{\text {mean }}$ coefficient was greater, which may be related to the emergence of the weed before the crop, or may be due to the lower environmental carrying capacity, defined as the environment's capacity for supporting lower plant density.

According to the inverse of the competitiveness indicators (Mamun, 2014), the weed density per square meter that causes $50 \%$ yield loss was 96,67 , and 28 plants per square meter for the high, medium, and low technological levels, respectively (Table 4). These values confirm that the environmental carrying capacity at the low technological level is significantly lower than at the other levels. The amount of resources limits the increase in density to higher levels, since the crop increases its ability to compete with weed in

Table 3. Sites, type of weed, sowing date, rice (Oryza sativa) cultivar, fertilizer, and technological levels in the four experiments used for validation.

\begin{tabular}{lccccc}
\hline Site & Weed $^{(1)}$ & Sowing date & Cultivar & ${\text { Fertilizer }\left(\mathrm{kg} \mathrm{ha}^{-1}\right)}$ & Technological level \\
\hline Santa Maria & Weedy rice & $11 / 6 / 2016$ & PUITÁ INTA CL & 250 5-15-20 N- $\mathrm{P}_{2} \mathrm{O}_{2} \mathrm{O}_{5}$ and 150 urea & High \\
São João do Polêsine & Weedy rice & $11 / 25 / 2016$ & IRGA 424 RI & 200 5-15-20 N-P $\mathrm{P}_{2} \mathrm{O}_{2} \mathrm{O}_{5}$ and 100 of urea & Medium \\
Cachoeirinha & Barnyard grass & $11 / 23 / 2016$ & IRGA 424 RI & Maximum recommended & High \\
Cachoeirinha & Barnyard grass & $11 / 23 / 2016$ & GURI INTA CL & Maximum recommended & High \\
\hline
\end{tabular}

${ }^{(1)}$ Weedy rice, Oryza sativa; and barnyard grass, Echinochloa spp.

Table 4. Classification of the $i_{\text {mean }}$ and $a_{\text {mean }}$ coefficients of the rectangular hyperbola, with their respective values of competitiveness $(\beta)$ and the density per square meter that causes a $50 \%$ yield loss (s) in the three technological levels for both weeds.

\begin{tabular}{lccc}
\hline Technological level & Coefficient $\mathrm{i}_{\text {mean }}$ & Coefficient $\mathrm{a}_{\text {mean }}$ & $\mathrm{s}$ \\
\hline & & Weedy rice (Orzya sativa) & \\
High & 1.04 & 100.00 & 0.0104 \\
Medium & 1.50 & 100.00 & 0.0150 \\
Low & 3.57 & 100.00 & 67 \\
\hline & & Barnyard grass (Echinochloa spp.) & 0.0357 \\
High & 4.70 & 101.63 & 0.0462 \\
Medium & 10.49 & 104.92 & 22 \\
Low & 15.51 & 96.88 & 0.1000 \\
\hline
\end{tabular}


environments with greater availability of resources, thus reducing yield loss by increasing its density (Agostinetto et al., 2013). Density initially increases freely, then its increase rate reduces to the extent of the resources that are becoming insufficient to sustain it; it stabilizes near the upper limit, since for the low technological level this upper limit may be much lower than that of the other two technological levels (Agostinetto et al., 2013).

The validation of the SimulArroz model using the yield loss submodule performed satisfactorily, and the RMSE values were lower than 2,433 $\mathrm{kg} \mathrm{ha}^{-1}$ (Table 5). These values are close to the $2,134 \mathrm{~kg} \mathrm{ha}^{-1}$ reported by Rosa et al. (2015). RMSEn values are below those reported by Silva et al. (2016), which ranged from 12.7 to $79.7 \%$; when compared with the 23.0 and $34.6 \%$ values obtained in the present study, they indicate that the yield loss submodule improved the simulation. The dw index, BIAS and COE coefficient show that the SimulArroz model with the weed competition module performed better for Santa Maria than for São João de Polêsine. A poorer performance of the model in São João do Polêsine may be related to the cultivar $\mathrm{x}$ technological level interaction. The IRGA 424 RI cultivar has a high tillering capacity, which renders it highly competitive with weeds, even under an intermediate technological level such as that of the farm in São João do Polêsine, where the yield loss for a range of about 30 to 90 weedy rice plants per square meter was not greater than $40 \%$, compared with more than $50 \%$ yield loss simulated by the model (Figure 1).

For barnyard grass, the classification of the rectangular hyperbola coefficients was similar to that observed for weedy rice (Table 4), but with higher values, due to the grass' greater competitiveness, faster growth, taller characteristic, and more efficient C4 metabolism (Tironi et al., 2009; Olajumoke et al., 2016). For the high, medium and low technological levels, the values of $i_{\text {mean }}$ were $4.70,10.49$ and 15.51 respectively, and for the $a_{\text {mean }}$ coefficient, 101.63, 104.92, and 96.88 respectively.

The unit loss (yield loss caused by one barnyard grass per square meter) increased considerably along with the reduction in technological level, at a much higher rate than that of weedy rice. This is because the environment supports fewer barnyard grass plants, that is, the environmental carrying capacity is much smaller for the barnyard grass and there are less resources available for its population to increase (Agostinetto et al., 2010, 2013). The rice yield loss caused by a barnyard grass plant per square meter under low technological level reached $15.51 \%$ and may reach close to $600 \mathrm{~kg} \mathrm{ha}^{-1}$ (Table 4).

Considering the $i_{\text {mean }}$ value found in the present study under low technological level, a barnyard grass plant per square meter can lead to a yield loss of around $15 \%$, which shows lower competitiveness with rice cultivation in this situation. Based on the inverse competitiveness $\beta$ (s) at the different technological levels, it was observed that the barnyard grass density per square meter that promotes $50 \%$ yield loss is always lower than that observed in weedy rice; the values for barnyard grass were 22, 10, and 6 plants per square meter for the high, medium, and low levels respectively (Table 4). These values confirm the low environmental carrying capacity for barnyard grass; even under the high technological level the density is lower than under the low technological level for the weedy rice, due to its fast growth, taller characteristic, and $\mathrm{C} 4$ metabolism (Olajumoke et al., 2016).

Table 5. Performance of the SimulArroz model with the yield loss module for weed competition with rice $(\text { Oryza sativa })^{(1)}$.

\begin{tabular}{|c|c|c|c|c|c|}
\hline Location /Cultivar & RMSE & RMSEn & $\mathrm{dw}$ & Bias & $\mathrm{COE}$ \\
\hline \multicolumn{6}{|c|}{ Weedy rice (Oryza sativa) } \\
\hline Santa Maria/PUITÁ INTA CL & 1,047 & 23.0 & 0.916 & 0.098 & 0.608 \\
\hline São João do Polêsine/IRGA 424 RI & 2,433 & 34.6 & 0.614 & -0.285 & 0.290 \\
\hline \multicolumn{6}{|c|}{ Barnyard grass (Echinochloa spp.) } \\
\hline Cachoeirinha/IRGA 424 RI & 1,492 & 18.9 & 0.965 & -0.029 & 0.855 \\
\hline Cachoeirinha/GURI INTA CL & 1,558 & 24.5 & 0.969 & -0.101 & 0.839 \\
\hline
\end{tabular}

(1)RMSE, root mean square error; RMSEn, normalized root mean square error; dw, modified index of agreement; Bias, bias index; and COE, NashSutcliffe efficiency coefficient. 
The performance of the SimulArroz model with the yield loss submodule was better for barnyard grass than for weedy rice; it's RMSE values were below $1,558 \mathrm{~kg}$ $\mathrm{ha}^{-1}$, and RMSE values, below $24.5 \%$ (Table 5). The $\mathrm{dw}$ and COE statistics indicate that the model has good accuracy and the BIAS index tended to underestimate yield, since the values for both weeds were negative.

Overall, the performance of the SimulArroz model in simulating the weed-crop competition in a wide range of weed densities in the field (both in experiments and in farms) was good. Very few crop simulation models
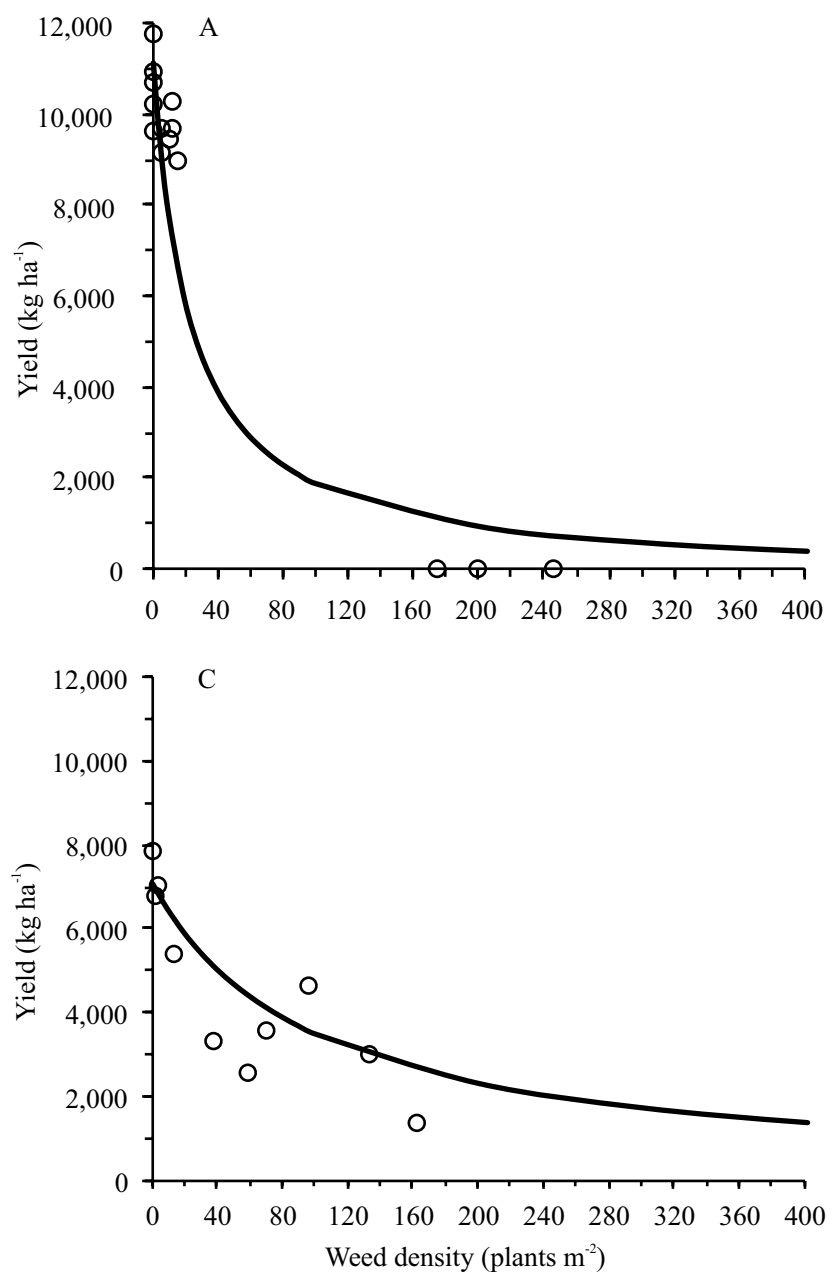

consider weed-crop competition to affect crop yield, and those that consider do so empirically. For instance, the Decision Support System for Agrotechnology Transfer does not have a weed-competition module, and the user can only choose weed control by herbicides when running a simulation (Hoogenboom, 2010). The SimulArroz model now has a module than can help consultants and farmers to understand how two of the major weeds affect rice yield and use this information for decision making.


Figure 1. Irrigated rice (Oryza sativa) yield as a function of barnyard grass (Echinochloa spp.) in the experiment carried out with the IRGA 424 RI (A) and GURI INTA CL (B) cultivars in the municipality of Cachoeirinha, in the state of Rio Grande do Sul, Brazil, and in the experiments with weedy rice and the PUITÁ INTA CL cultivar in Santa Maria (C), and with IRGA 424 RI in São João do Polêsine (D), also in the state of Rio Grande do Sul. 


\section{Conclusions}

1. The yield loss approach is suitable to model the weed-crop competition between weedy rice (Oryza sativa) and barnyard grass (Echinochloa spp.) with irrigated rice.

2. A yield loss submodule of the competition between weedy rice and barnyard grass with irrigated rice crops improves the SimulArroz model's predictive capacity.

\section{Acknowledgments}

To Coordenação de Aperfeiçoamento de Pessoal de Nível Superior (Capes), for scholarships awarded.

\section{References}

ADATI, C.; OLIVEIRA, V.A.; KARAM, D. Análise matemática e biológica dos modelos de estimativa de perdas de rendimento na cultura devido à interferência de plantas daninhas. Planta Daninha, v.24, p.1-12, 2006. DOI: https://doi.org/10.1590/S010083582006000100001 .

AGGARWAL, P.K.; KALRA, N.; CHANDER, S.; PATHAK, $H$. InfoCrop: a dynamic simulation model for the assessment of crop yields, losses due to pests, and environmental impact of agro-ecosystems in tropical environments. I. Model description. Agricultural Systems, v.89, p.1-25, 2006. DOI: https://doi. org/10.1016/j.agsy.2005.08.001.

AGOSTINETTO, D.; FLECK, N.G.; RIZZARDI, M.A.; BALBINOT JUNIOR, A.A. Dano econômico como critério na decisão sobre manejo de genótipos de arroz concorrentes em arroz irrigado. Pesquisa Agropecuária Brasileira, v.40, p.1-9, 2005a. DOI: https://doi.org/10.1590/S0100-204X2005000100001.

AGOSTINETTO, D.; FLECK, N.G.; RIZZARDI, M.A.; BIANCHI, M.A.; MENEZES, V.G. Níveis de dano econômico para decisões de controle de genótipo simulador de arrozvermelho em arroz irrigado. Revista Brasileira de Agrociência, v.11, p.175-183, 2005 b.

AGOSTINETTO, D.; FLECK, N.G.; RIZZARDI, M.A.; VIDAL, R.A.; COSTA, E.L.N. Influência de cultivares de arroz e épocas da adubação nitrogenada nas relações de interferência da cultura com cultivar simulador de infestação de arroz-vermelho. Planta Daninha, v.22, p.185-193, 2004. DOI: https://doi.org/10.1590/ S0100-83582004000200003.

AGOSTINETTO, D.; FONTANA, L.C.; VARGAS, L.; MARKUS, C.; OLIVEIRA, E. de. Habilidade competitiva relativa de milhã em convivência com arroz irrigado e soja. Pesquisa Agropecuária Brasileira, v.48, p.1315-1322, 2013. DOI: https://doi.org/10.1590/ S0100-204X2013001000002.

AGOSTINETTO, D.; GALON, L.; MORAES, P.V.D.; TIRONI, S.P.; DAL MAGRO, T.; VIGNOLO, G.K. Interferência de capimarroz (Echinochloa spp.) na cultura do arroz irrigado (Oryza sativa) em função da época de irrigação. Planta Daninha, v.25, p.689-696, 2007. DOI: https://doi.org/10.1590/S010083582007000400005

AGOSTINETTO, D.; GALON, L.; SILVA, J.M.B.V.; TIRONI, S.P.; ANDRES, A. Interferência e nível de dano econômico de capimarroz sobre o arroz em função do arranjo de plantas da cultura. Planta Daninha, v.28, p.993-1003, 2010. Número especial. DOI: https://doi.org/10.1590/S0100-83582010000500007.

AMINPANAH, H.; SHARIFI, P.; FIROUZI, S. Interference interactions of two species of Echinochloa genus with rice. Chilean Journal of Agricultural Research, v.72, p. 364-370, 2012. DOI: https://doi.org/10.4067/S0718-58392012000300010.

BECK, M.; ULGUIM, A. da R.; CONCEIÇÃO, A.M. da; RICHTER, G.L.; STRECK, N.A. Perda de produtividade e nível de dano em cultivares do sistema Clearfield ${ }^{\circledR}$ em função da competição com capim arroz (Echinochloa spp.). In: CONGRESSO BRASILEIRO DE ARROZ IRRIGADO, 10., 2017, Gramado. Intensificação sustentável: anais. Porto Alegre: Sosbai, 2017. p.217-220

BRASIL. Ministério da Agricultura, Pecuária e Abastecimento. Zoneamento Agrícola de Risco Climático. 2018. Available at: $<$ http://www.agricultura.gov.br/politica-agricola/zoneamentoagricola/>. Accessed on: Feb. 152018.

CONAB. Companhia Nacional de Abastecimento. Boletim da Safra de Grãos. Available at: <https://www.conab.gov.br/infoagro/safras/graos/boletim-da-safra-de-graos >. Accessed on: Nov. 112019.

COUSENS, R. A simple model relating yield loss to weed density. Annals of Applied Biology, v.107, p.239-252, 1985. DOI: https://doi.org/10.1111/j.1744-7348.1985.tb01567.x.

FAO. Food and Agriculture Organization of the United Nations. Database-agricultural production. Available at: <http:// www.fao.org/faostat/en/\#rankings/countries_by_commodity $>$. Accessed on: Nov. 112019

FLECK, N.G.; AGOSTINETTO, D.; RIZZARDI, M.A.; BIANCHI, M.A.; MENEZES, V.G. Interferência de plantas concorrentes em arroz irrigado modificada por métodos culturais. Planta Daninha, v.22, p.19-28, 2004. DOI: https://doi.org/10.1590/ S0100-83582004000100003.

GALON, L.; AGOSTINETTO, D.; MORAES, P.V.D.; TIRONI, S.P.; DAL MAGRO, T. Estimativa das perdas de produtividade de grãos em cultivares de arroz (Oryza sativa) pela interferência do capim-arroz (Echinochloa spp.). Planta Daninha, v.25, p.697-707, 2007. DOI: https://doi.org/10.1590/S0100-83582007000400006.

HOOGENBOOM, G. The decision support system for Agrotechnology Transfer (DSSAT): past, current and future developments. In: BIOLOGICAL SYSTEMS SIMULATION CONFERENCE, 40., 2010, Maricopa. Program and Summaries. [Gainesville: University of Florida], 2010. p.13-15.

LI, T.; ANGELES, O.; MARCAIDA III, M.; MANALO, E.; MANALILI, M.P.; RADANIELSON, A.; MOHANTY, S. From ORYZA2000 to ORYZA (v3): an improved simulation model for rice in drought and nitrogen-deficient environments. Agricultural and Forest Meteorology, v.237-238, p.246-256, 2017. DOI: https://doi.org/10.1016/j.agrformet.2017.02.025. 
MAMUN, A.A. Modelling rice-weed competition in directseeded rice cultivation. Agricultural Research, v.3, p.346-352, 2014. DOI: https://doi.org/10.1007/s40003-014-0138-2.

MENEZES, V.G.; ANGHINONI, I.; SILVA, P.R.F. da; MACEDO, V.R.M.; PETRY, C.; GROHS, D.S.; FREITAS, T.F.S. de; VALENTE, L.A. de L. Projeto 10: estratégias de manejo para aumento da produtividade e da sustentabilidade da lavoura de arroz irrigado do RS: avanços e novos desafios. Porto Alegre: IRGA, 2012. 104p.

MOON, B.-C.; WON, J.-G.; KIM, Y.-L.; KIM, S.-W.; LEE, I.-Y.; PARK, J.-E.; KIM, D.-S. Prediction of rice yield and economic thresholds by some weeds-rice competition in transplanted rice cultivation. Korean Journal of Weed Science, v.31, p.289-293, 2011. DOI: https://doi.org/10.5660/KJWS.2011.31.3.289.

NASH, J.E.; SUTCLIFFE, J.V. River flow forecasting through conceptual models'. Part I - A discussion of principles. Journal of Hydrology, v.10, p.282-290, 1970. DOI: https://doi.org/10.1016/0022-1694(70)90255-6.

OLAJUMOKE, B.; JURAIMI, A.S.; UDDIN, K.; HUSNI, M.H.A.; ALAM, A. Competitive ability of cultivated rice against weedy rice biotypes - a review. Chilean Journal of Agricultural Research, v.76, p.243-252, 2016. DOI: https://doi.org/10.4067/ S0718-58392016000200015.

RIBAS, G.G.; STRECK, N.A.; DUARTE JUNIOR, A.J.; NASCIMENTO, M.F. do; ZANON, A.J.; SILVA, M.R. da. Number of leaves and phenology of rice hybrids simulated by the SimulArroz model. Revista Brasileira de Engenharia Agrícola e Ambiental, v.21, p.221-226, 2017. DOI: https://doi.org/10.1590/1807-1929/agriambi.v21n4p221-226.

RIBAS, G.G.; STRECK, N.A.; LAGO, I.; ZANON, A.J.; WALDOW, D.A.G.; DUARTE JUNIOR, A.J.; NASCIMENTO, M. de F. do; FONTANA, V. Acúmulo de matéria seca e produtividade em híbridos de arroz irrigado simulados com o modelo SimulArroz. Pesquisa Agropecuária Brasileira, v.51, p.1907-1917, 2016. DOI: https://doi.org/10.1590/s0100204x2016001200001.

ROSA, H.T.; WALTER, L.C.; STRECK, N.A.; DE CARLI, C.; RIBAS, G.G.; MARCHESAN, E. Simulação do crescimento e produtividade de arroz no Rio Grande do Sul pelo modelo SimulArroz. Revista Brasileira de Engenharia
Agrícola e Ambiental, v.19, p.1159-1165, 2015. DOI: https://doi.org/10.1590/1807-1929/agriambi.v19n12p1159-1165.

RUBIN, R.S.; LANGARO, A.C.; MARIANI, F.; AGOSTINETTO, D.; BERTO, R.M. Habilidade competitiva relativa de arroz irrigado com arroz-vermelho suscetível ou resistente ao herbicida imazapyr + imazapic. Arquivos do Instituto Biológico, v.81, p.173-179, 2014. DOI: https://doi.org/10.1590/1808-1657001242012.

SAMBORANHA, F.K.; STRECK, N.A.; UHLMANN, L.O.; GABRIEL, L.F. Modelagem matemática do desenvolvimento foliar em mandioca. Revista Ciência Agronômica, v.44, p.815-824, 2013. DOI: https://doi.org/10.1590/S1806-66902013000400019.

SILVA, M.R. da; STRECK, N.A.; FERRAZ, S.E.T.; RIBAS, G.G.; DUARTE JÚNIOR, A.J.; NASCIMENTO, M. de F. do; ALBERTO, C.M.; MACHADO, G.A. Modelagem numérica para previsão de safra de arroz irrigado no Rio Grande do Sul. Pesquisa Agropecuária Brasileira, v.51, p.791-800, 2016. DOI: https://doi.org/10.1590/S0100-204X2016000700001.

STRECK, N.A.; LAGO, I.; OLIVEIRA, F.B.; HELDWEIN, A.B.; AVILA, L.A. de; BOSCO, L.C. 2011. Modeling the development of cultivated rice and weedy red rice. Transactions of the ASABE, v.54, p.371-384, 2011. DOI: https://doi.org/10.13031/2013.36234.

TANG, L.; ZHU, Y.; HANNAWAY, D.; MENG, Y.; LIU, L.; CHEN, L.; CAO, W. RiceGrow: a rice growth and productivity model. NJAS - Wageningen Journal of Life Sciences, v.57, p.8392, 2009. DOI: https://doi.org/10.1016/j.njas.2009.12.003.

TIRONI, S.P.; GALON, L.; CONCENÇO, G.; FERREIRA, E.A.; SILVA, A.F.; ASPIAZÚ, I.; FERREIRA, F.A.; SILVA, A.A.; NOLDIN, J.A. Habilidade competitiva de plantas de arroz com biótipos de capim-arroz resistente ou suscetível ao quinclorac. Planta Daninha, v.27, p.257-263, 2009. DOI: https://doi.org/10.1590/S0100-83582009000200007.

WALTER, L.C.; ROSA, H.T; STRECK, N.A.; FERRAZ, S.E.T. Adaptação e avaliação do modelo InfoCrop para simulação do rendimento de grãos da cultura do arroz irrigado. Engenharia Agrícola, v.32, p.510-521, 2012. DOI: https://doi.org/10.1590/ S0100-69162012000300010.

WILLMOTT, C.J.; ACKLESON, S.G.; DAVIS, R.E.; FEDDEMA, J.J.; KLINK, K.M.; LEGATES, D.R.; O'DONNELL, J.; ROWE, C.M. Statistics for the evaluation and comparison of models. Journal of Geophysical Research, v.90, p.8995-9005, 1985. DOI: https://doi.org/10.1029/JC090iC05p08995. 